\title{
Enstitü Çıkışlı Yazarların Köy Gerçeğine Yaklaşımları (1950-1960)
}

\section{Approaches to Village Reality of the Institute Graduate Writers (1950-1960)}

\section{Halil İbrahim Ünser ${ }^{1}$ (1)}

${ }^{1}$ Dr. Öğr. Üyesi, Kapadokya Üniversitesi, Beşeri Bilimler Fakültesi, Türk Dili ve Edebiyatı Bölümü, Nevşehir, Türkiye

\section{ORCID: H.İ.Ü. 0000-0001-5456-0837}

Sorumlu yazar/Corresponding author: Halil İbrahim Ünser,

Kapadokya Üniversitesi, Beşeri Bilimler Fakültesi, Türk Dili ve Edebiyatı Bölümü, Nevşehir, Türkiye

E-mail: halil.unser@kapadokya.edu.tr

Başvuru/Submitted: 11.04.2021

Revizyon Talebi/Revision Requested: 11.06.2021 Son Revizyon/Last Revision Received: 24.06.2021 Kabul/Accepted: 08.11.2021

Online Yayın/Published Online: 27.12.2021

\section{Attf/Citation:}

Unser, H. I. (2021). Enstitü çıkışlı yazarların köy gerçeğine yaklaşımları (1950-1960). TUDED, 61(2), 709-722

https://doi.org/10.26650/TUDED2021-913548

\section{ÖZET}

1950'li yıllara kadar toplumcu gerçekçi Türk romanında sosyalist söylemi kırsal yaşantıda doğrulama çabası ön plana çıkmış ve bu çaba, devrimci bir siyasi özne işlevi görecek sanayi proletaryası yokluğunu köydeki çatışma unsurlarıyla telafi etme esasına dayandırılmıştır. 1950'li yıllarda ise Cumhuriyet'in değerlerini köylere ileterek köylüleri bilinçlendirecek öğretmenleri yetiştirmek üzere kurulan Köy Enstitülerinin ilk mezunları, kendilerini toplumcu gerçekçi edebiyatın içinde bulmuş ve zaman içinde onun önemli bir kolunu oluşturmuşlardır. Aydınlanmacı bir ütopyanın hayata geçirilmesi için kilit rol oynaması planlanan bu öğretmen yazarlar sosyalist eğilimlerinin yanında Cumhuriyet değerlerine bağlılıklarından kopmamışlar, bu yönleriyle dünya görüşü olarak diğer toplumcu gerçekçi yazarlardan farklılaşmışlardır. Bu farklılığın sanatsal boyutunun köyün içinden gelen bu yazarların köy gerçeğine bakışında belirginleştiği görülmektedir. $\mathrm{Bu}$ çalışmada Mahmut Makal, Fakir Baykurt, Talip Apaydın'ın, 1950-1960 yılları arasında yayımlanan, köy hayatının gerçekliklerini, yetiştikleri ve görev yaptıkları köyden bakarak dile getirdikleri eserlerinde işlenen siyasi meseleler yukarıda verilen hususlar çerçevesinde ele alınmış, bu açıdan temsil niteliği gösteren, köylerdeki iktisadi durumun çarpıcı bir biçimde gösterildiği Bizim Köy, kapsamlı bir köy-köylü çözümlemesi olan Yılanların Öcü ve tarımda makineleşme meselesine giriş özelliği taşıyan Sarı Traktör isimli eserlerde köye ve köylüye yaklaşımın gerçekçilik ekseninde ana toplumcu gerçekçi akımdan farklılıkları incelenmiştir. Anahtar Kelimeler: Köy Enstitüleri, Gerçekçilik, Bizim Köy, Yılanların Öcü, Sarı Traktör

\section{ABSTRACT}

By the 1950s, efforts to justify a socialist discourse on rural life came to the fore in the socialist realist Turkish novel. This endeavor sought to compensate for the absence from the villages of an industrial proletariat that might function as a revolutionary political subject with elements of conflict. The village institutes had been founded to communicate the values of the republic to the villages, and their first graduates created effective works in the 1950s. These authors maintained republican values alongside their socialist tendencies, a fact that differentiated them from other socialist realist authors. The artistic dimension of this distinctiveness is evident in the way these authors portray the reality of village life. In this study, political issues mentioned in the works of three institute graduate authors (Mahmut Makal, Fakir Baykurt, Talip Apaydın) are analyzed within the framework outlined above. Differences from the 
main socialist realist movement, particularly the degree of realism, in approach to the village and the peasantry are examined in three works by the aforementioned authors. Respectively, these are Bizim Köy (which depicts the striking situation in the villages), Yılanların Öcü (a comprehensive village-peasant analysis), and Sarı Traktör (which can be regarded as an introduction to the issue of mechanization in agriculture).

Keywords: Village Institutes, Realism, Bizim Köy, Yılanların Öcü, Sarı Traktör

\section{EXTENDED ABSTRACT}

By the 1950s, the village had become a political subject in Turkey. In this context, the existence of writers of rural origin, novelists who had been educated in the village institutes and who addressed the subject of villages and villagers, represents a special literary phenomenon.

Despite some common interests, such as class conflict and patterns of exploitation of villagers by local political and religious forces, institute authors differed from mainstream socialist realist writers in some respects. Reformism, democracy, and enlightenment are among these. Institute authors sought to expose the sufferings of villagers to the authorities and intellectuals. This attitude suggests that the authors in question did not really wish to give up on the system. According to the authors themselves, the main problem for Turkish villagers was that reforms could not reach them. They further argue that, if reforms were extended to the peasantry and the development efforts of the republic sustained in the villages, class inequality and social injustice would be eliminated.

Mahmut Makal took a revolutionary step by revealing the reality of village life in Bizim Köy. In Yllanların Öcü, Fakir Baykurt reflected on the issue of land reform in the social life of villagers. Conversely, Talip Apaydın covered the period of agricultural mechanization in Sarı Traktör, but with a different perspective. These three authors differ from earlier novelists who wrote about the village, primarily in that they address the realities of the village and its inhabitants without a romantic revolutionary attitude.

The divergence from mainstream socialist realist writers can clearly be observed in Yllanların Öcü. The novel's district governor character is an important demonstration of the institute writers' views on the state. The character is similar to the positive civil servant type of the National Literature period. Likewise, the idealized character who resists cruelty in Yllanların Öcü is a woman, as often seen in this period. This choice of characters can be regarded as a reference by the author to republican values and the republic's founding ideology.

As the title of the work emphasizes, it depicts an alternate village and draws a line from which there is no return to the reality of a village narrative. The villager characters of Baykurt, another institute writer who followed Makal, are too lively to be neglected. Baykurt sought traces of universal values in the small lives of Makal's villagers and attempted to make them feel politically right amid the conflicts of this small world. 
Another problem for the villager, in addition to sharing land, is the cultivation of existing land, i.e., labor. The sharecropping system is described often in the village novel. Talip Apaydin, also a writer from a village, reflects on agricultural mechanization and its effects on village evolution in his novel Sarı Traktör.

Makal and Baykurt portray villagers as comfortable and content with themselves and not desiring better lives. The works of these two authors present this cultural facet as the most serious obstacle to the development of the village and the peasantry. Apaydın, however, offers a different perspective on the matter by addressing the peasant's ambitions in Sarl Traktör. In this novel, Apaydin sought to depict a young peasant generation desiring the development that can only come with mechanization.

The social realist novel genre had a tendency to avoid an understanding of art in which the ideological dimension dominates while artistic aspects are disregarded. However, a common pattern can be observed, especially in socialist realist novels written before the 1960s. In very few works were the ideological and aesthetic aspects successfully balanced. Nonetheless, just such a balance was attained in Bizim Köy, and at an unprecedented level. The minutely detailed world of Fakir Baykurt's heroes offers a comprehensive analysis of life. The theme of the tractor, left unfinished by Apaydın, is the real agenda of the village, as Kemal Tahir puts it, and is significant in that it represents the village's transformation.

Institute writers dealt with certain issues as a continuation of the official founding ideology of the republic. Among their themes were raising awareness of villagers, providing villagers with land, ensuring development through education, and promoting industrialization in agriculture. 


\section{GİRIŞ}

Cumhuriyet'in ilanından sonra köylerin kalkındırılması ve köylülerin refah durumlarının iyileştirilmesi amacıyla iktisadi hayatta olduğu kadar eğitim ve kültür hayatında da reformlar başlatılmıştır. Toprak reformu ile köylünün toprak sahibi olması ve ağa baskısından kurtarılması hedeflenirken köylüyü bilinçlendirmek ve devrimin ilkelerini Anadolu’nun her köşesine yayabilmek için ise köylere öğretmen gönderilmesine karar verilmiştir. Bunun için ilk girişim 1937 yılından itibaren orduda çavuş ve onbaşı olarak görev yapmış kimselerin altı aylık bir kursun ardından "eğitmen" olarak köylere gönderilmeye başlanması olmuştur (Yıldız ve Akandere, 2017, s. 281). 1940 yılından itibaren ise köylüye temel eğitimin dışında bölgenin tarımsal üretimine uygun modern tarım teknikleri, güzel sanatlar, çeşitli zanaatlar ve sağlık gibi konularda da eğitim verecek öğretmenleri yetiştirmek üzere teorik eğitim ve uygulamanın bir arada olduğu daha kapsamlı bir proje olarak Köy Enstitüleri kurulmuştur. Köy çocuklarının yine köylerine dönerek buralarda görev bilinciyle hizmet etmelerini hedefleyen bu proje ile köylerin kalkınması ve köylülerin eğitilmesinin sorumluluğu o köylerden yetişecek öğretmenlere bırakılmış ve hem geri kalmış bölgelerin kalkınması hem de göçün önlenmesi amaçlanmıştır. ${ }^{1}$

Üçü de aydınlanmacı dünya görüşüne sahip olan dönemin Cumhurbaşkanı İsmet İnönü, Millî Eğitim Bakanı Hasan Âli Yücel ve İlköğretim Genel Müdürü İsmail Hakkı Tonguç’un önderliğinde gelişen Köy Enstitüleri, köylüyü bilinçli bir sınıf hâline getirmeyi hedeflemiş ve bu hedefe uygun bir şekilde yapılandırılmıştır. Bu yönüyle Köy Enstitüleri, askerlerin öncülüğündeki bir halk eğitimi hareketi olan Köy Muallim Mektepleri'nden farklı olarak -Yakup Kadri’nin Ankara romanında tasvir ettiği Türkiye ütopyasını andırır şekilde- aydınlanmacı bir ütopya niteliği taşımıştır. 1945 yılından itibaren dünyanın komünist ve kapitalist ideolojiler arasında kutuplaşmaya başlamasıyla birlikte ise bu ütopya iyiden iyiye savunmasız kalmış ve Yüksek Köy Enstitüsü çıkışlı yönetici ve eğitmen yazarlar kendilerini Marksist-sosyalist akımın içerisinde bulmuşlardır.

Ellili yıllarla birlikte artan makineleşme ve teşviklerin etkisiyle tarımda yaşanan atılım; işgücüne ihtiyacın azalması, kentlere göçlerin başlaması ve toprak dağılımında dengesizliklerin artması gibi sorunları da beraberinde getirmiştir. ${ }^{2}$ Mehmet Kaplan, bu dönemde edebiyatta köy üzerinde sınıfsal eşitsizlik konusunu işleyen toplumcu gerçekçilere Enstitü çıkışlı yazarların eklenmesini köy romanının iki koldan yürümeye başlaması olarak nitelendirmiştir. Kaplan'a göre "köyü kısa sürede tanıma fırsatı bulan veya zaman zaman köyle ilişkileri olan" bu yazarlar, eserlerinde "bu yolla edindikleri izlenimleri veya köy hakkında araştırmaya dayanan düşüncelerini yazmışlardır” (Kaplan, 1997, s. 136-137).

1 Şehirlerde okuyan öğrencilerin köylere dönmekte isteksiz olmaları dolayısıyla Enstitülerin köylere yakın yerlere yapılması ve buralarda yetişen öğretmen adaylarının yirmi yıl zorunlu hizmete tâbi tutulması kararlaştırılmıştır.

2 Bu konuda daha ayrıntılı bilgi için bkz. (A. Makal, 2001; Yurtoğlu, 2014, s. 260-283) Ayrıca Enstitülü romancılardan farklı olarak köylerdeki olumlu ekonomik ve toplumsal değişimlere odaklanan çalışma için bkz. (Keleş ve Türkay, 1962, s. 491) 
Kaplan'ın da işaret ettiği gibi Enstitü çıkışlı bu romancılar, köy hayatına toplumcu gerçekçi bakış açısıyla bakan ve sosyalist eğilimler taşıyan ve köy temalı romanlar yazan diğer toplumcu gerçekçi yazarlardan, gerçekliğe yaklaşımları bakımından ayrılmışlardır. Ana akım toplumcu gerçekçi yazarlarda köy ve köylü siyasi fikirlerin dile getirilmesinde bir araç olup, bu durumun en net ifadelerinden birisi Orhan Kemal'in şu sözlerinde somutlaşmıştır: "Memleketimizin insanlarının kalkınmasını, refahını, yükselmesini istedim. Bu işin de köyden başlaması kanısına vardım.” (akt. Özer, 2011, s. 32) Böylesine bir motivasyonun köy gerçekliğini tüm çıplaklığıyla ortaya koyma gibi bir çerçevenin dışına işaret ettiğini ifade etmek mümkündür.

Köyün gerçekliğini yaşamış olan Enstitü çıkışlı romancılar, ideolojilerini yaymak, halkı bu doğrultuda bilinçlendirmek ve harekete geçirmek veya siyasi kavramları tartışmak gibi amaçlar için köy gerçekliğini feda etmemişlerdir. Bu açıdan Irmak (2018, s. 27-28) "köy temalı romancılar"'ın köyü “hemen her seferinde daha büyük bir meseleyi göstermek, açıklamak ya da çözüm önerisi sunmak, bir tarihselleştirme veya ideolojik konumlandırmada bulunmak için” araçsallaştırdığını, Enstitü çıkışlı romancıların ise "köyü kendi iç dinamikleriyle kaydedip, tekil ve dışa kapalı bir bakışla "aktarmak” kaygısı taşıdıklarını ifade etmektedir.

Ana akım toplumcu gerçekçi romanda köy, ağa ve işbirlikçi çıkar gruplarının merkezde olduğu bir sömürü sistemi olarak resmedilirken Enstitü çıkışlı köy romanlarında toplumsal sav, köylünün gerçekliğine dayandırılmaktadır. Ellili yıllarda köylü yavaş yavaş kendi topraklarına sahip olmaya başlamakta ve geçmişteki ağalık düzeninin oluşturduğu sömürü ortamının yerini, muhtar ve köy kurulları gibi yerel yöneticilerin çıkar sistemi almaktadır. Bu romanlarda sömürü eleştirisi yanında makineleşme ve okullaşma ile köylünün hayatında meydana gelen değişimlere, köylerin ekonomik, toplumsal ve kültürel yapılarındaki gelişmelere geniş yer verilmiştir.

Marksist-sosyalist geleneğin bir parçası olan toplumcu gerçekçi romancılarımızın gerçekçiliğe yaklaşımları elbette ilgili dönemin Marksist ideoloji tartışmalarından etkilenmiştir. Gerçeklik ve gerçekçilikle ilgili eserleriyle tanınan teorisyen Georgy Lukács, kurguda şablonları kullanan toplumcu gerçekçi edebiyatı gerçeklikten kopma yönünden eleştirir (Lukács, 1969, s. 107). Lukács'a göre toplumcu gerçekçilerin bir kısmı Marksist-Leninist nesnelcilikten vazgeçmiş ve böylelikle kuram ve gündelik hayat ilişkisi basit bir niteliğe bürünmüş, kuram ve uygulama arasında sahte bir kutuplaşma ortaya çıkmıştır (s. 136). Stalinci dönemde Marksizmin dolaysız bir şekilde gündelik sorunlara uygulanması, edebiyatta asıl sorunların ele alınamamasına ve belli çözüm yollarının dogmacı bir biçimde benimsenmesine yol açmıştır. Edebiyat, Stalin döneminde benimsenen toplumcu gerçekçilikle birlikte "artık toplumsal hayatın devingen çelişkilerini yansıtmaz olmuş, soyut bir 'doğru'nun açıklanmasına dönüşmüştür” (s. 138). Bu tür edebiyatta araştırma, propaganda ve kışkırtma arasındaki ilişkilerin sıralaması da tam tersine dönmüş, araştırmaya dayanan güçlü bir propagandayla yapılması gereken kışkırtma, propaganda ve araştırmanın çıkış noktası hâline gelmiştir (s. 138). Lukács, yazarların gündelik politikayla ilgilenmeleri ve bu gibi sorunları ele alma yollarını bulmakta özgür bırakılmaları gerektiğini düşünür. Çünkü bu tarz bir siyasi edebiyat, "Stalinci açıklama edebiyatı"ndan üstündür (s. 138). Buna göre toplumcu gerçekçi edebiyatın birçok örneğinde gerçeğin ötesine geçen kimi 
durumların bulunduğu ifade edilebilir. Başarılı bir edebiyat için toplumcu gerçeklikle eleştirel gerçeklik "bağlaşmalı" ve bu "bağlaşma" neticesinde yazar sanatını "eleştirel gerçekliğin sanatsal mirasının” (s. 156) üstüne inşa etmelidir. Stalin döneminde birçok sosyalist yazar Lenin'in de eleştirdiği "komünist boş yücelik"e (s. 156) tutunmuştur. Eleştirel gerçeklikle bağlarını koparmayan yazarlar ise ya yazmaktan vazgeçmiş veya sosyalizm karşıtına dönüşmüşlerdir. Lukács gerçekçilik üzerine düşündüğü bu kapsamlı eserini “sosyalist demokrasinin” gelişmesi için eleştirel gerçekçiliğin yaşayan geleneklerine önemli görev düştüğünü ifade ederek tamamlar (s. 156).

1950’li yılların öncesine dair Türk edebiyatındaki gerçekçilik tartışması üzerine en çok kafa yoran -ancak kendisi de özellikle siyasi ahlak tutumu dolayısıyla eserlerinde sıklıkla gerçekliği geri planda bırakabilen kahramanlar ve sahneler yaratan- Kemal Tahir, "insan gerçeklerini görmezden gelme”yi "cezası çekilecek bir suç” olarak görmekte ve gerçekçi romanın "bir toplumun belli zümrelerinin gelecekte karşılaşacakları yeni durumlarda nasıl davranabileceklerini kestirmesine" yarayacağını ifade etmektedir (akt. Bozdağ, 1995, s. 189). Buna ilave olarak Tahir, gerçekçiliği insanlık tarihinin en yüksek basamağı olarak değerlendirmekte (s. 190) ve Türk sosyalist edebiyatının en meşhur kahramanı Ince Memed'i gerçekle bağlantısı olmayan "klişe bir kahraman yaratma çabası" olarak değerlendirmektedir (Tüzer ve Hüküm, 2017, s. 263).

Çalışmada 1950-1960 yılları arasında yazılmış olan ve Enstitü çıkışlı köy kökenli yazarların köy gerçekliğine bakışını göstermesi bakımından önemli ve etkili üç eser seçilmiş ve incelenmiştir. Bunlardan ilki Mahmut Makal'ın, köydeki hayata dair tuttuğu notların derlenmesinden oluşan ve Türk toplumuna köy hayatının gerçekliğini gösteren Bizim Köy olmuştur. Bu eser, köy gerçekliğinin olumsuz taraflarının sansürsüz ve filtresiz bir biçimde sergilenmesi açısından toplumcu gerçekçi edebiyata yeni bir bakış açısı getirmesi nedeniyle önem taşımaktadır. Bizim Köy’e kadar çatışmanın sahnesi olarak tasvir edilip çoğu zaman romantik bakış açısıyla dönüşümün başlangıç noktası olarak kurgulanan köy, Bizim Köy'den sonra toplumun büyük bir bölümünün geri kalmışlığının ve gelir dağılımındaki adaletsizliğin en açık göstergesine dönüşmüştür.

\section{ACI GERÇEK: BİZIM KÖY}

Yukarıda bahsedildiği üzere kırklı yılların başında köylü, kurucu ideoloji tarafından "milletin efendisi" ilan edilmiş ve köy, aydınlanmanın merkezi olarak belirlenmiştir. Bu doğrultuda köylerde bilimi ve sanatı yaşatma iddiasıyla Köy Enstitüleri kurulmuştur. Ancak CHP iktidarının son bulduğu 1950 yılında yayımlanan Bizim Köy’ü okuyanlar köye ilişkin ideal ve hayallerle hiçbir şekilde bağdaşmayan sert bir gerçekçilikle karşılaşırlar. Aksaray’ın bir köyünde yaşanan sefaleti tüm açıklığıyla ortaya koyan eser bu yönüyle yayınlandığı dönemde büyük ilgi uyandırmıştır. Makal, köylü dâhil kimsenin yüzleşmek istemediği gerçekliği kendi yaşadıklarından yola çıkarak en açık hâliyle dile getirmiş ve bu açıdan takipçisi olan Enstitü çıkışlı yazarları etkilemiştir. 
Mahmut Makal'ın genç bir öğretmenken aldığı köy notlarından oluşan Bizim Köy, yerel ağızla yazılmış olan diyalogları ile dikkat çekmektedir. Makal, Bizim Köy adlı eserinde, Enstitülerin çabalarına rağmen köylerde kalkınma hamlesi başlatmanın ne kadar güç olduğunu, hatta köylerin insanca koşullardan ne kadar uzak olduğunu anlatmıştır. Soğuk, yoksulluk ve hastalık dolu ve her şeye rağmen cehaletin hüküm sürdüğü bu ortamda kendisi gibi öğretmenleri ayakta tutan şeyin, geleceğe dair taşıdıkları "ümidin sıcaklığı" olduğunu vurgulayan Mahmut Makal (1973, s. 9-10), verdiği mücadeleyi bir savaş olarak gördüğünü ifade etmiştir. Yazarın ele aldığı İç Anadolu köyünde içerisinde oturulacak bir konut, soğuktan koruyacak giysiler ve yakıt, karınları doyuracak yiyecekler gibi temel ihtiyaçlar bile karşılanamamakta, tüm aile toprak zeminli, isli tek bir odanın içinde yaşamakta, hastalıklardan her yıl çok sayıda çocuk ölümü gerçekleşmektedir. Ulaşım ve iletişim imkânları da çok kısıtlı olduğundan ülkede nelerin olup bittiğinin bile öğrenilmesi mümkün olmamaktadır. Modernleşmenin unsurları köylere henüz uğramamıştır. Ataerkil bir aile yapısının bulunduğu köyde iş yükünün çoğu kadının üzerindedir ancak toplumsal yapı içerisinde kadının hiçbir söz hakkı bulunmamaktadır (M. Makal, 1973, s. 7-9).

Makal, eserinde köyün ve köylülerin durumuyla ilgili yetkililere yapılan şikâyetlerden bir sonuca varılamamasını, köyün gerçeklerinin bilinmemesi ve bunları yazacak aydınların ortaya çıkmamasına bağlar. Yazar, Yakup Kadri’nin Yaban romanında köy gerçeğinden kısmen bahsetmesinin bile Türk köyüne iftira olarak görülerek büyük tepkilere yol açtığını ifade eder (M. Makal, 1973, s. 42).

Makal'ın köyünde durumu diğerlerinden daha iyi olan iki grup bulunmaktadır. Bunlar muhtarlar ve şeyhlerdir. Muhtar olmanın koşulları varlıklı olmak ve çok sayıda akrabaya sahip olmaktır. Muhtarlık için uygun olup olmamak bir kriter olarak görülmemekte ve muhtarlar çoğu zaman, askerde okumayı öğrenmiş ya da biraz geniş görüşlü olanlar yerine cahiller arasından seçilmektedir. Bunlar çeşitli vaatlerde bulunarak işlerini masrafsızca köylülere gördürmektedirler (M. Makal, 1973, s. 79-80). Şeyhler de çalışmamakta ve tüm ihtiyaçlarını köylülerden sağlamaktadırlar. Yoksullaştıkça tarikatlara ve şeyhlere daha çok bağlanan köylüler, sorunlarının sebebinin Allah'ı unutmuş olmaları olduğuna inanarak aç veya yakıtsız kalmayı göze alarak ellerindeki avuçlarındaki her şeyi şeyhlerine verirler (s. 110, 114-5). Şeyhlerin sözlerini hiç kimse sorgulamaz ve onların ihtiyaçlarını karşılamak için gösterilen dayanışma, köyün kalkınması için gösterilmez (s. 115). Hafızlara da rağbetin çok olduğundan bahseden yazar, velilerin çocuklarını kendisinin öğretmenlik yaptığı okula göndermektense hafıza göndermeyi tercih etmelerinden yakınmıştır. Okulun binası yağan yağmurların etkisiyle kısmen çökerken öğrencilere ders görebilecekleri bir alan tahsis etmeye yanaşmayan köylüler, hafızların çocuklara ders vermeleri için ise her türlü imkânı sağlarlar. Zira onlara göre devletin okulu dünyalık bir iş olup kendilerine gerekense öteki dünyadır (s. 129, 131).

Makal'ın, köyün ve köylülerin durumlarını tüm çarpıcılığıyla ortaya koyması büyük bir tepkiye yol açmış ve yazar baskıların sonunda görevinden ayrılmak zorunda kalmıştır (Atıcı, 
2018, s. 4). Ancak onun öncülüğünü yaptı̆ğ $1^{3}$ Enstitü çıkışlı köy edebiyatı, başka yazarların da katkılarıyla gelişmiştir. Bir röportajında, İsmail Hakkı Tonguç'un Köy Enstitüleri’nin temel vazifesini, "yedi asırdır suskun olan köylüleri konuşmaya, düşünmeye ve söylemeye alıştırmak" olarak tanımladığını ifade eden Mahmut Makal'ın (2012), kendi yazdıklarıyla bu vazifeyi gerçekleştirmiş olduğu söylenebilir.

Makal ile birlikte köy ve köylüler ilk kez bir köylünün gözünden anlatılmış (Irmak, 2018, s. 105) ve Bizim Köy gerçekten de kimsenin gerçeklerinden haberdar olmadığ1 Türk köyünü görünür hâle getirmiştir. Sınıfsal çatışmanın tarafı olarak köylünün gerçekliğinin bu şekilde ortaya konması, diğer taraftan Türk Marksist-sosyalist hareketinin temel açmazlarının da görülmesine olanak sağlayacak tartışmaların başlamasına neden olmuştur. Bu açıdan Bizim Köyün, kendisini takip edecek eserlere yol gösterdiğini ifade etmek mümkündür.

Bu eserler arasında en büyük yankıyı uyandıran ise, daha sonra beyaz perdeye de taşınan, Fakir Baykurt'un Yılanların Öcü adlı romanı olmuştur. Yazara soruşturma açılmasına ve öğretmenlikten uzaklaştırılmasına neden olan bu eser, hem üslup hem de karakterlerin nitelikleri açısından dikkate değer bir romandır.

\section{BAYKURT'TAN GERÇEKÇİ BİR ÇÖZÜMLEME: YILANLARIN ÖCÜ}

Fakir Baykurt'un 1958 yılında yayımlanan Yllanların Öcü adlı romanı 1950-1960 y1lları arasında yazılan diğer propaganda romanlarından gerçekliği ele alma yönüyle ayrılır. Enstitü çıkışlı köy romanlarının içerisinde ekonomik eşitsizliklere vurgunun en çok yapıldığ 1 roman olan Yılanların Öcü’nde Baykurt, CHP döneminde Çiftçiyi Topraklandırma Kanunu (1945) kapsamında başlamış ve 1950 yılında Demokrat Parti'nin iktidara gelmesinin ardından da toprak sahiplerine sağlanan kolaylıklarla devam etmiş olan köylülere toprak satılmasını ve bunun getirdiği yeni sorunları konu etmiştir. Baykurt eserinde, köylülerin ağır borçlar altına girerek toprak sahibi olmaya çalıştıkları bu dönemde, toprakların büyük kısmının yine köylerdeki varlıklı burjuvazi tarafından satın alındığını, ağa baskısının yerini Demokrat Parti döneminde gücü artan köy burjuvazisinin baskısına bırakmış olduğunu ve köylerde sınıfsal ayrımların derinleştiğini savunur (Tatarlı ve Mollof, 1969, s. 217-218).

Baykurt'un, kendi memleketi olan Burdur'daki bir köyde geçen romanı, ekonomik ve siyasi güçleri bulunmayan, bu nedenle de uğradıkları her türlü haksızlığa boyun eğmeye mahkûm

3 Makal'a köyde yaşadıklarını yazmasını tavsiye etmiş olan ve bu notları Varlık'ta yayınlayan Yaşar Nabi, Bizim Köy'ün bir Anadolu köyünün acı gerçeğini tüm açıklığıyla ortaya koyduğunu ve dolayısıyla Türk köylüsünün insanlık haklarına kavuşması uğrunda yazılmış bir ithamnâme olarak değerlendirilebileceğini ifade etmiştir (akt. Kabaklı, 2012, s. 1332). Sadun Tanju'ya göre (1973) ise bu durum onu siyasi iktidarlar için bir düşman hâline getirmiş ve Türk toplumuna karşı vazifesini yerine getirmiş bir öğretmen olan Makal, o toplumun gözleri önünde manevî bir işkence ile cezalandırılmıştır. Bu açıdan denebilir ki onun suçu, köyü yazmaktır. Çetin Altan, Türk halkı için savaşan Türk aydınının, tüm dünya tarafından alkışlansa bile Türkiye'nin yerli kompradoru tarafından yerin dibine batırılmaya çalışacağını söyleyerek Makal'ın gördüğü tepkinin şaşırtıcı olmadığını imâ etmiş (M. Makal, 1973, s. 173), Melih Cevdet Anday da (1950) Mahmut Makal gibi yazarların Türkiye'nin gerçek yüzünü göstererek kendi içlerine kapanmış aydınları uyandırıp utandıracağını belirtmiştir. 
oldukları düşünülen Kara Bayram ve ailesinin, köydeki ekonomik ve siyasi gücü ellerinde bulunduran Muhtar ve Köy Kurulu üyeleri karşısındaki haklarını arama mücadelelerini konu etmektedir. Romanda kanunsuz bir toprak satışına karşı verilen mücadelede fiziksel saldırıları da içeren yıldırma çabaları anlatılırken, okuyucu köyün gerçekliği içerisinde ekonomik eşitsizlikler ve adalet meselesi üzerine düşünmeye sevk edilmektedir.

Romanın genelinde yoksul ve güçsüz köylülerin, başlarına gelenlere rıza göstermeye alıştırılmış ve adalet bulmaktan ümitlerini kesmiş oldukları, bu karamsarlıklarının da üstünler ve yöneticiler tarafından pekiştirilmesi vurgulanmaktadır: Yoksul köylünün yerel siyasi gücün temsilcisi olan muhtar ile bozuşması köylüye felâket getirecektir (Baykurt, 2018, s. 185). Muhtar, güçlü olandan yana olduğundan, onun uyguladığı kanun da güçlü olanın lehine işlemektedir. Nitekim köylülerin Bayram ve ailesini haklı bulmalarına rağmen güçlüler karşısında kazanma şanslarının olmadığını düşünmeleri ve onları davalarından vazgeçirmeye çalışmaları, köylülerde yıllar boyunca yerleşmiş olan çaresizlik hissinin bir ifadesi olarak canlandırılmaktadır. Baykurt'un zulme itiraz eden ideal kahramanı Irazca, romanın direnmekten çekinmeyen tek kahramanıdır. Irazca romanın sonunda yılanlar dahi kendilerine yapılan kötülüklerin intikamını, üzerinden yıllar geçtikten sonra bile mutlaka aldıkları düşüncesinden hareketle, insanın bu kadar çabuk yılmasına tepki gösterir. Millî Mücadele romanlarının direnişçi güçlü kadın tipi Yılanların Öcü’nde adalet uğruna savaşan bilge Anadolu kadını olarak görünür. Hasan Âli Yücel, Irazca’yı, “Türk köylüsünü ... sömürenlere karşı (verilen) savaşı, İstiklâl Savaşı'nın devamı belleyen, Atatürk devrimlerine inanmış bütün Türklerin anası" olarak tanımlamıştır (Yücel, 2000, s. 139).

Bir öğretmen olan yazar, alışılagelinen sömürü düzenini sarsan gelişmeler olarak gördüğü eğitimin yaygınlaşmaya ve geleneksel yöntemlerin değişmeye başlamasının önemini vurgulamış ve bunun örneğini, haksızlık karşısında ezilenden yana duran genç bir kaymakam üzerinden vermiştir. Ayrıca Baykurt, köyün tanıtılmasının önemini vurgulamış ve şehirli bazı yazarlar için bir heves olarak tanımladığı köy romanları yazmayı ve Türk köyünün acısını, ellerinden geldiğince duyurmaya çalışmayı, kendisi gibi köy hayatını bilen, köylüyü tanıyan Enstitü çıkışlı yazarlar için bir hak ve görev olarak nitelemiştir (Tatarlı ve Mollof, 1969, s. 211-212). Diğer taraftan Baykurt, köylere dair bıraktıkları bu eserlerin ilerleyen yıllarda politikacılara, işverenlere ve diğer sorumlulara fayda sağlayacak belgeler olacağını belirtmiştir (Naci, 1990, s. 261). Makal gibi eseri dolayısıyla baskı gören Baykurt'un sıra dışı ve kışkırtıcı eseri, köyün ve köylünün durumunu en etkileyici biçimde veren romanlardan biri olarak büyük bir ilgi yakalamayı başarmıştır. ${ }^{4}$

Baykurt eserinde herhangi bir sistem önerisinde bulunmamış, yalnızca köyün ve köylünün içinde bulunduğu zorlu koşulların iyileştirilebilmesi için bunların farkına varılmasını sağlamaya

4 Yaşar Kemal (2000), bunun, Baykurt'un anlattığı yokluk, yılgınlık ve cehalet içindeki Türk köyü ve köylüsünün, yazarın kendi gerçeğindeki köy ve köylü olmasına, bu nedenle de Baykurt'un yapmacık olmamasına bağlamıştır (s. 150). Tatarlı ve Mollof (1969), y1lanları, Türk toplumunda "....sömürücüler ve zalimlerin sembolü" olarak tanımlamış ve romanın, "Demokrat Parti döneminde yaşanan siyasi, toplumsal ve ahlâkî çöküşü tüm çıplaklığ 1 ile gösterdiği" yorumunda bulunmuşlardır (s. 221) 
çalışmakla yetinmiştir. Erkan Irmak (2018, s. 249) bunu, yazarın içinde yetiştiği için yakından tanıdığı, öğretmen olarak döndükten sonra ise farklı bir bakışla taradığı köyün gerçekliğini kayıt altına alma çabası olarak ifade etmiştir.

Beraberinde bir sistem eleştirisi getirmemekle birlikte köylünün istek ve ihtirasları üzerine düşünen bir diğer roman ise dönemin bir başka Enstitülü yazarı olan Talip Apaydın'dan gelmiştir. Apaydın'ın Sarı Traktör isimli eseri, eksik de olsa köyün tarımdaki teknolojik gelişmeler dolayısıyla nasıl bir dönüşüm geçirdiğinin ele alınması açısından önem taşımaktadır.

\section{KÖYLÜNÜN GERÇEK GÜNDEMİ: SARI TRAKTÖR}

Talip Apaydın, makineleşmenin köydeki yansımasını işleyen ve 1958 yılında yayımlanan Sarı Traktör'de ellili yıllarla birlikte Türkiye'de tarımda makineleşmenin artmasının etkisiyle başlayan modernliğe geçiş sürecini ve tarımda modern tekniklerin kullanılması ihtiyacını konu etmiştir. Bu dönemde henüz çoğunlukla geleneksel yöntemlerle tarım yapmayı sürdüren Türk köylüsünün perişanlık içindeki çalışma koşullarını, bu ağır şartların yol açtığı tükenmişliği, herhangi bir siyasi ideolojinin savunuculuğunu yapma gayesi taşımaksızın son derece gerçekçi bir biçimde tasvir eden Apaydın, romanında köylünün zorlu yaşamını kolaylaştıracak modern bir araç olarak traktör kullanılmaya başlanmasının önemini göstermek istemiştir.

Romanda, köyde yeni kullanılmaya başlanan traktöre heves eden bir genç olan Arif ile bu yeni araca karşı önyargılı davranan babası İzzet Ağa arasındaki çekişme etrafında dönemin Türk köylüsünün yenilikler ve modernleşme karşısındaki tutumları kuşak çatışması üzerinden işlenmiştir. Arif' in traktör tutkusunun, traktöre sahip olabilmeyi hayatındaki her şeyin ve herkesin önüne koyacak kadar şiddetli olması, genç nüfusun geleneksellik ve yenilik karşısındaki içsel çatışmasını gözler önüne serdiği gibi, ilk kez köylünün hırslarını da ortaya koymuştur (Erol, 2005, s. 112). Arif' in, geleneksel yöntemlerden ayrılmak istemeyen babasının baskılarına rağmen hayalinden vazgeçmemesi, Makal'ın ve Baykurt'un çizmiş olduğu aza kanaat etmeye ve baskı karşısında pes etmeye alışmış, gelişmeye kapalı köylü tipolojisinden kopuşu simgelemektedir.

Bir köy öğretmeni olarak Apaydın, Anadolu köylerinde eğitim yoluyla benimsetilmeye çalışılan çağdaşlık ve modernliğin, gelenekçi toplumda gericilik ve bağnazlıkla çatışmasını ve ona üstün gelmesini, traktöre karşı olan bu yaklaşım üzerinden anlatma yoluna gitmiş (Nurdan, 2020, s. 309) ve traktörün köye girmesinin sağlanmasında köy öğretmeninin yönlendirici etkisinin önemine vurgu yapmıştır. Romandaki öğretmeninin, İzzet Ağa karşısındaki tutumu Enstitülerin hedeflemiş oldukları bu bilinçlendirme ülküsünün bir yansıması olarak değerlendirilebilir. Bununla birlikte yazar, Makal ve Baykurt'ta olduğu gibi köylüyü bilinçlendiren aydına yönelik oluşan tepkiyi de dile getirmiştir. Nitekim çocukların aklına traktör almak gibi “yenilikçi fikirlerin” sokulmasından öğretmenin sorumlu tutulduğu görülmektedir (Apaydın, 2019, s. 43). 
Romanında zamanın koşullarına ve gelişime ayak uydurmanın gerekliliğini vurgulamaya ağırlık vermiş olan Apaydın, makineli üretime geçişin yaratacağı toplumsal değişimlere değinmeyerek romanı traktörün gelişiyle bitirmiş ve traktörü, yalnızca traktör sahibine sağlayacağı fayda ile sınırlı olarak göstermiştir (Naci, 2019, s. 411). ${ }^{5}$

\section{SONUÇ}

Ellili y1llarla birlikte köyün politik bir özne hâline gelmesine paralel olarak, köy ve köylü konusunu işleyen köy kökenli yazarlar, köy gerçekliğine katkılarıyla kaleme aldıkları eserlerin özel bir edebî olgu hâline gelmesini sağlamışlardır. Mahmut Makal Bizim Köy ile köy gerçeğinin gözler önüne serilmesinde devrim niteliğinde bir adım atmış, Fakir Baykurt Yılanların Öcü’nde toprak reformu konusunun köylünün sosyal hayatına yansımasını ele almış, Talip Apaydın ise Sarl Traktör'de tarımda makineleşme dönemini farklı bir bakış açısıyla işlemiştir. Bu üç yazar, kendilerinden önce köye dair eser veren romancılardan, öncelikle eserlerinde köyün ve köylünün gerçekliğini ele almak ve romantik devrimci tutumdan uzak durmuş olmak bakımından ayrışmaktadırlar.

Yaşar Kemal, Orhan Kemal ve Kemal Tahir gibi ana akım toplumcu gerçekçi yazarlar için köy, öncelikle siyasi söylemlerini doğrulamak için bir araç, aktarılmak istenen tezi sergileyen bir sahne olarak kullanılmıştır. Köyü şematik toplumcu gerçekçi bakış açısıyla değerlendirmiş olan bu yazarlardan farklı olarak Enstitülü yazarların eserlerinde köyün rahatsız edici gerçekleri gözler önüne serilerek Türk köyünün ve köylüsünün sefalet ve cehaletine dikkat çekilmiş, köy ideolojik araç veya sahne olmaktan çıkmış, ele alınmak istenen olgunun kendisi hâline dönüşmüştür.

Köylerdeki sınıf çatışmaları, yerel siyasi ve dinî güçlerin temsilcilerinin sürdürdükleri sömürü düzeni, köylülerin yaşamlarındaki zorluklar ve benzeri konular açısından tespit edilebilecek ortak yönlere karşın Enstitülü yazarlar, ana akım toplumcu gerçekçi yazarlardan inkılapçı, demokrat ve aydınlanmacı yönleriyle ayrılırlar. Enstitülü yazarlar köylünün sorun ve acılarını yetkililere ve aydınlara göstermeyi ve böylelikle bir fayda sağlamayı hedeflemişlerdir. $\mathrm{Bu}$ tavır söz konusu yazarların esasen sistemden ümitlerini kesmediklerini göstermektedir. Enstitülü yazarlara göre Türk köylüsünün asıl sorunu inkılapların köye ulaşamamasından kaynaklanmaktadır. Buna göre inkılaplar köylüye özümsetilirse ve Cumhuriyetin kalkınma hamlesine köyden, köylüden devam edilebilirse, sınıfsal eşitsizliğin ve sosyal adaletsizliğin önüne geçilebilecektir.

5 Kemal Tahir bu hususu, esas olanın insanın değişen koşullara ayak uydurması olduğunu belirterek ve kitabın değişimi göstermek yerine başlaması gereken yerde bittiğini söyleyerek eleştirmiştir (Irmak, 2018, s. 154). Tahir'in vurguladığı bu tutum, köy romancılarına yönelik olarak yapılan, iyi bildikleri köy gerçeğini yansıtırken yaşam koşullarının zorluğunu ve haksızlıkları sergilemekle yetinme, insan unsurundan ziyade meselelere önem verme eleştirilerini de doğrular niteliktedir (Kaplan, 1997, s. 557). Fethi Naci (2019) de bu anlamda Apaydın'ın romanında köy gerçekliklerini birebir vermiş olduğunu belirtmekle birlikte köye bir gözlemci olarak bakmakla yetinmiş olduğu şeklindeki eleştirisini getirmiştir (s. 412-413). 
Mahmut Makal, eserinin isminde de vurguladığı üzere farklı bir köyü, kendi gözlemleriyle resmini çizdiği köyünü anlatmış ve köy anlatısının gerçekliğine geri dönülmesi mümkün olmayan bir çizgi çekmiştir. Onu takip eden Enstitülü bir diğer yazar olan Baykurt'un köylü karakterleri ihmal edilemeyecek kadar canlıdır. Baykurt, Makal'ın gerçek köylülerinin küçük hayatlarında evrensel değerlerin izlerini aramış ve bu küçük dünyanın çatışmalarında siyasi açıdan doğruyu hissettirmeye çalışmıştır. Bu dünya görüşünü en etkili biçimde yansıtan eserlerden olan Yılanların Öcü’nde yukarıda sayılan farklılıklar açıkça gözlemlenebilir. Baykurt'un romanındaki kaymakam karakteri Enstitü çıkışlı yazarların devlete bakışını göstermek bakımından önemlidir. Kuyucaklı Yusuf'un zaafları olan etkisiz kaymakamı Baykurt’ta doğruluğu temsil eden bir tip olarak karşımıza çıkar. Sabahattin Ali’nin kaymakamı özünde iyi niyetli ve yardımsever bir insan olmasına rağmen çıkar gruplarının sömürü düzenini sürdürmesine engel olamaz. Bu açıdan bakıldığında bu karakterinin Tanzimat romanındaki Osmanlı bürokratı tipini andırdığı ifade edilebilir. Baykurt'un kaymakamı ise kötü yönetimi temsil eden muhtarın karşısında köylünün yanında Cumhuriyet değerlerini temsil eden olumlu bir karakterdir ve çatışmada köylüden yana tavır alır. Bu kaymakam karakteri Millî Edebiyat döneminin olumlu devlet memuru tipine oldukça yakındır. Yılanların Öcü'nde zulme karşı direnen idealize edilmiş karakter, Millî Edebiyat döneminde sıklıkla görüldüğü üzere bir kadındır. Bu husus da yazarın Cumhuriyet değerlerine ve kurucu ideolojiye yaptığı gönderme olarak değerlendirilebilir.

Köylü için toprağın paylaşılması kadar önemli bir sorun da var olan toprağın işlenmesi, yani işgücüdür. Köy romanında sıklıkla ortakçılık (yarıcılık) sistemi anlatılır. Talip Apaydın, Sarı Traktör isimli romanında yine köyün içinden gelmiş bir yazar olarak -her ne kadar makineleşmenin toplumsal yaşantıdaki etkilerini göstermemekle eleştirilse de- tarımda makineleşmenin köyün ve köylünün kalkınmasına, yarıcılık sistemine olan etkileri üzerine düşünür. Mahmut Makal ve Fakir Baykurt köylünün aza kanaat etmeye alışkın olduğunu ve daha iyi bir yaşama heves etmediğini düşünmektedir. Bu kültürel öge bu iki yazarın eserlerinde köyün ve köylünün gelişmesindeki en önemli engel olarak gösterilir. Apaydın ise Sarı Traktör'de köylünün ihtiraslarını ele alarak konuya öncüllerinden farklı bir bakış açısı getirir. Apaydın romanında genç köylü neslin makineleşmeyle gelecek olan kalkınma ve gelişmeyi istediğini, bunun için çabalayacak ve başaracak güçte olduğunu göstermek istemiştir. Tabiî ki bu kalkınma hamlesinde köylünün yanında öğretmen duracaktır.

Şematik toplumcu gerçekçi romanda araştırma, propaganda ve kışkırtma döngüsü tersine çevrilmiş ve sonuç olarak araştırmaya dayanan güçlü bir propagandayla yapılması gereken kışkırtma, başlangıç noktası haline dönüşmüştür. Bu durum da edebi eseri Lukács’ın deyimiyle “toplumsal hayatın devingen çelişkilerini yansıtmaz" hale getirmiş, "soyut bir doğrunun açıklanmasına” dönüştürmüştür (Lukács, 1969, s. 138).

Bu çalışmada seçilen eserlerde toplumcu gerçekçi akım içerisinde Mahmut Makal, Fakir Baykurt ve Talip Apaydın'ın içinden çıktıkları köy yaşantısını aktarırken gerçekçiliğe nasıl bir katkıda bulundukları Lukács'ın eleştirisi çerçevesinde gösterilmeye çalışılmış ve birtakım 
sonuçlara ulaşılmıştır. Bu sonuçlara yönelik olarak ilkin, Mahmut Makal'ın Bizim Köy'de gerçekçilikle yakaladığı fikrî ve sanatsal dengenin o güne kadar görülmemiş bir düzeyde olduğu söylenebilir. Fakir Baykurt'un kahramanlarının küçük ve detaylı olarak anlatılan dünyaları ise -her ne kadar çıkar gruplarına işaret eden şematik yanları bulunsa da- köy gerçeğini gözler önüne seren kapsamlı bir yaşam çözümlemesi sunar. Apaydın’ın -Kemal Tahir'in deyimiyle yarım bıraktığı- traktör dikkati, köyün gerçek gündemidir ve köylünün kalkınma isteğini, köy yaşantısının iktisadi değişim ve dönüşümünün insan hayatına yansımasını gösterebilmek açısından önemlidir. Ana amaç olarak toplumsal çatışmayı yakalama ve bu çatışmanın insan üzerindeki etkilerini anlatma iddiasındaki bu köy kökenli romancıların seçilen eserlerinde toplumcu gerçekçilikle eleştirel gerçekçiliği Lukács'1n deyimiyle "bağlaştırma" çabası görülmektedir.

Enstitü çıkışlı yazarlar ellili yılların sonrasında da toplumcu hassasiyetlerle ve eleştirel gerçekçi tutumlarıyla köylüyü bilinçlendirerek irtica ile savaşma, köylüyü topraklandırma, Cumhuriyetin değerlerini köylüye benimseterek nihai çözüme ulaşma, eğitim yoluyla kalkınmayı sağlama, tarımda ve kalkınmada sanayi hamlesi gerçekleştirme gibi konuları işleyen eserler üretmeye devam etmişlerdir.

Hakem Değerlendirmesi: Dış bağımsız.

Çıkar Çatışması: Yazar çıkar çatışması bildirmemiştir.

Finansal Destek: Yazar bu çalışma için finansal destek almadığını beyan etmiştir.

Peer-review: Externally peer-reviewed.

Conflict of Interest: The author has no conflict of interest to declare.

Grant Support: The author declared that this study has received no financial support.

\section{KAYNAKÇA/REFERENCES}

15 Haziran 1995 tarihli 6032 sayılı Çiftçiyi Topraklandırma Kanunu Erişim adresi: https://www.resmigazete. gov.tr/arsiv/6032.pdf

Anday, M. C. (1950). “Bizim Köy’e Dair”, Yaprak Dergisi, (21). Erişim adresi: https://www.tustav.org/ yayinlar/sureli_yayinlar/yaprak/yaprak-21.pdf

Apaydın, T. (2019). Sarl Traktör. (6. bs.). İstanbul: Literatür Yayınları.

Atıc1, E. (2018). Mahmut Makal Onurlu Bir Mücadele Bıraktı Gelecek Kuşaklara. Köy Enstitüleri Bülteni, 59,4 .

Baykurt, F. (2018). Yılanların Öcü. (26. bs.). İstanbul: Literatür Yayıncılık.

Bozdağ, İ. (1995). Kemal Tahir 'in Sohbetleri. (2. bs.). İstanbul: Emre Yayınları.

Erol, K. (2005). Talip Apaydın'ın Hayatı, Roman ve Öyküleri Üzerine Bir Araştırma. (Doktora Tezi). Yüzüncü Y1l Üniversitesi Sosyal Bilimler Üniversitesi, Van.

Irmak, E. (2018). Eski Köye Yeni Roman: Köy Romanının Tarihi, Kökeni ve Sonu (1950-1980). İstanbul: İletişim Yayınları. 
Işkın, E. C. (2019). Köy Enstitüsü Kökenli Romancıların Toplumsal Sorunlara İlgisindeki Değişim: Duisburg Üçlemesi Örneği. İstanbul: İstanbul Arel Üniversitesi Sosyal Bilimler Enstitüsü Yayımlanmamış Yüksek Lisans Tezi.

Kabaklı, N. (2012). Türk Edebiyatı'nda Etnografik Bir Yazın Olarak 'Bizim Köy'. Turkish Studies, 7(1), $1331-1337$.

Kaplan, R. (1997). Cumhuriyet Dönemi Türk Romanında Köy. Ankara: Akçağ Yayınları.

Keleş R. ve O. Türkay (1962). Köylü Gözüyle Türk Köylerinde İktisadi ve Toplumsal Değişme. Ankara Üniversitesi Siyasal Bilgiler Fakültesi Dergisi, 17(2), 483-491.

Kemal, Y. (2000). "Yılanların Öcü Üzerine Birkaç Söz”. Anadolu Aydınlanmacısı Fakir Baykurt. (Feridun Andaç, Haz.). İstanbul: Evrensel Basım Yayın.

Lukács, G. (1969). Çăgdaş Gerçekçiliğin Anlamı. (Cevat Çapan, Çev.). 2. Basım, İstanbul Payel Yayınevi.

Makal, A. (2001). Türkiye'de 1950-1965 Döneminde Tarım Kesiminde İşgücü ve Ücretli Emeğe İlişkin Gelişmeler. Ankara Üniversitesi Siyasal Bilgiler Fakültesi Dergisi, 56(3), 103-140.

Makal, M. (1973). Bizim Köy. İstanbul: Derinlik Yayınları.

Makal, M. (2012). “Mahmut Makal Köy Enstitüsü Anılarını Anlatıyor”, Pera Müzesi. Erişim adresi: https:// www.youtube.com/watch?v=Ua5NYWY9Yv8\&ab_channel=PeraM\%C3\%BCzesi

Naci, F. (1990). 100 Soruda Türkiye’de Roman ve Toplumsal Değişme. (2. bs.). İstanbul: Gerçek Yayınevi.

Naci, F. (2019). Yüz Yılın 100 Türk Romanı, (11. bs.). İstanbul: Türkiye İş Bankası Kültür Yayınları.

Nurdan, G. T. (2020). Gelenek ve Modernizm Bağlamında 'Sarı Traktör' Romanındaki ‘Traktör' Simgesi. ÇAKÜ Sosyal Bilimler Enstitüsü Dergisi, 11(1), 309-320.

Özer, H. (2011). 12 Eylül 1980 Darbesinin Türk Romanına Yansıması. (Doktora Tezi). İstanbul Üniversitesi Sosyal Bilimler Enstitüsü, İstanbul.

Tanju, S. (1973). Cumhuriyet Gazetesi, 2 Temmuz 1973. Erişim adresi: https://www.cumhuriyetarsivi. com/katalog/192/yazar/13612-SADUN+TANJU/1973/7/2.xhtml

Tatarlı, İ. ve R. Mollof (1969). Hüseyin Rahmi'den Fakir Baykurt'a Marksist Açıdan Türk Romanı. İstanbul: Habora Kitabevi Yayınlar1.

Tüzer, İ. ve M. Hüküm (2017). Türk Romanının Kanonu Karşısında Kemal Tahir. Uluslararası Türkçe Edebiyat Kültür Eğitim Dergisi, 6(1), 256-276.

Yıldız, N. ve Osman A. (2017). Köy Enstitülerinin İdeolojik Yapısı. Çăğdaş Türkiye Tarihi Araştırmaları Dergisi, XVII(35), 275-316.

Yurtoğlu, N. (2014). Demokrat Parti Dönemi Tarım Politikalarl ve Siyasi, Sosyal, Ekonomik Hayata Tesirleri (1950-1960). (Doktora Tezi). Hacettepe Üniversitesi Atatürk İlkeleri ve İnkılap Tarihi Enstitüsü, Ankara.

Yücel, H. Â. (2000). “Türk Edebiyatına Kendi Giren Köylü”, Anadolu Aydınlanmacısı Fakir Baykurt. (Feridun Andaç, Haz.). İstanbul: Evrensel Basım Yayın. 